\title{
FACTORS INFLUENCING HUMAN RELIABILITY OF HIGH TEMPERATURE GAS COOLED REACTOR OPERATION
}

\author{
Sigit Santoso \\ Center for Nuclear Reactor Technology and Safety (PTKRN) - BATAN \\ Puspiptek Serpong, Gedung 80, Tangerang Selatan 15310 \\ Email: sigitsan@batan.go.id \\ Diterima editor: 26 Agustus 2016 \\ Diperbaiki: 22 September 2016 \\ Disetujui untuk publikasi: 29 September 2016
}

\begin{abstract}
FACTORS INFLUENCING HUMAN RELIABILITY OF HIGH TEMPERATURE GAS COOLED REACTOR OPERATION. Operator roles and intervene actions on the operation of gas cooled reactor would be different compared to their roles in other reactor types. Analysis of operator performance and the influencing factors can be conducted comprehensively in Human Reliability Analysis (HRA). Using HRA, the impact of human errors on the system and the ways to reduce human error impact and frequency can be idenfified. The paper discusses factors influencing reactor operator performance to response to the cooling accident of the high temperature gas cooled reactor (HTGR). Analysis and qualification of influencing factors, which are performance shaping factors (PSF), were conducted based on time reliability curve and Cognitive Reliability and Error Analysis Method (CREAM). Based on time reliability curve, results showed that time variable contributes to the improvement of operator performance ( $\mathrm{PSF}<1$ ), especially when the safety features of the system properly work as in the design. Based on CREAM, it can be identified that in addition to the time variable, human machine interface design and sufficiently training also contribute to the improvement of operator performance. This study found that total PSF equals to 0.25 , in which the positive dominant factor is time variable whose PSF is 0.01 and the negative dominant factors are procedure and working cycle whose PSF is 5 . Those PSF values reflected the multiplier factors to the human error probability. The analysis of performance shaping factors should be developed on the other operation and accident scenarios of HTGRs prior to be further applied for a comprehensive assessment and analysis of human reliability and for the design of human machine interface system at control room.
\end{abstract}

Keywords: PSF, HTGR, human operator, control room, human reliability

\section{ABSTRAK}

FAKTOR-FAKTOR YANG MEMPENGARUHI KEANDALAN MANUSIA PADA PENGOPERASIAN REAKTOR TEMPERATUR TINGGI BERPENDINGIN GAS. Peran dan tindakan operator pada reaktor berpendingin gas akan berbeda dengan peran operator pada operasi tipe reaktor lain. Analisis unjuk kerja operator dan faktor yang berpengaruh dapat dilakukan secara komprehensif melalui analisis keandalan manusia(HRA). Melalui HRA dampak dari kesalahan manusia pada sistem maupun cara untuk mengurangi dampak dan frekuensi kesalahan dapat diketahui. Makalah membahas faktor yang berpengaruh pada tindakan operator, yaitu pada kejadian kecelakaan pendingin reaktor gas bersuhu tinggi-HTGR. Analisis untuk kualifikasi faktor pembentuk kinerja(PSF) dilakukan berdasarkan kurva keandalan fungsi waktu, dan metode keandalan manusia yang dikembangkan berdasar pada aspek kognitif yaitu Cognitive Reliability and Error Analysis Method (CREAM). Hasil analisis berdasar kurva keandalan fungsi waktu menunjukkan komponen waktu berkontribusi positif pada peningkatan keandalan operator $(P S F<1)$ pada kondisi semua fitur keselamatan berfungsi sesuai rancangan. Sedangkan pada metoda analisis dengan pendekatan kognitif CREAM diketahui selain faktor ketersediaan waktu, faktor pelatihan dan rancangan HMI juga berkontribusi meningkatkan keandalan operator. Faktor pembentuk kinerja keseluruhan diketahui sebesar 0,25 dengan faktor kontribusi positif dominan atau berpengaruh pada penurunan kesalahan manusia adalah ketersediaan waktu (PSF=0,01), dan faktor kontribusi negatif dominan adalah prosedur dan siklus kerja (PSF=5). Nilai PSF tersebut sebagai faktor pengali dalam perhitungan probabilitas kesalahan manusia. Analisis faktor pembentuk kinerja perlu dikembangkan pada skenario kejadian lain untuk selanjutnya digunakan untuk perhitungan dan analisis keandalan manusia yang komprehensif dan perancangan sistem interaksi manusia mesin di ruang kendali.

Kata kunci: PSF, HTGR, operator, ruang kendali, keandalan manusia 


\section{INTRODUCTION}

Design of new reactor type such as high temperature gas cooled reactor (HTGR) has been much improved and has a higher level in safety. This reactor type has passive safety systems that do not much depend on engineered system. Consequently, the reactor operation and accident management of HTGR becomes simpler compared to those of other reactor designs such as PWR. Moreover, operator roles and other factors influencing the performance of operational actions can also be reduced by implementing inherent control system and automation. Therefore, the possibility of decreasing on operator performance and vigilance affected by the high automation system, inherent control and regulation, and minimum intervention in the reactor operation becomes a concern of many researches [1,2].

In contrast to the engine or components of a nuclear installation, human factors tend to be complex, and their performances are also influenced by various factors. Analysis on human performances and influencing factors are implemented in various industrial areas, especially industries that have a high hazard potential, such as nuclear reactors, chemical industry, oil and gas industry, as well as the transport and aviation industry [3-5]. Therefore, the researches for assessing human performance shaping factors on human reliability analysis are developed, such as during reactor operation in control room, conducting maintenance activities, and determining operation risk scale as well [6-8].

In new-generation reactors, such as HTGRs where the safety systems have been designed much better than the previous generation, human factor approach is used to optimize the performance of safety functions, and to improve the effectiveness of reactor operation. Information on factors that influences performance shaping factors (PSF) are essential as a basis in attaining a good reactor design and safety operation. With this regard, determining the level of automation, human-machine function allocation, design of auxiliary systems, and other significant aspects can be made more precise through task analysis and comprehensive consideration on human factor [9$10]$.

There are many PSF variables, which should be considered in the analysis of human reliability. Up to this time, there are no standards and provisons which specify how the most ideal number of PSF or should be used in HRA [8,11]. Some methods even use only one variable of PSF in the analysis, but there are a number of methods that consider more than fifty PSFs on their analytical approach. The number of PSF used does not linearly correspond to valid analysis results. In this study, according to operator actions applied as a response to the accident, the availability of time is considered as one of important element in the PSF. Some other PSF components to be considered are the adequacy of the training, the availability of plans and procedures, the adequacy of HMI and operation equipment, the number of targets to be achieved, the quality of the cooperation of personnel, and working conditions $[6,12,13]$.

In HTGR operation, the time availability is well considered through the design of safety systems that do not require the operator to take immediate actions for off-normal situations. This is quite different from other reactors such as PWR where the response to the accident conditions tend to be required immediately. However, from the human factors perspective, there are many factors that should be considered in order to minimize human error probability, other than the time availability. Therefore, factors contribute to the operator performance in HTGR operation and how those factors influence operator error probability need to be evaluated. The purpose of this study is to analyse and quantify the performance shaping factors of human reliability in the HTGR operation. A cooling accident in HTGR was used as a case study. Two methods are applied in the methodology, i.e. human reliability analysis as a function of time (single PSF) and Cognitive Reliability and Error Analysis Method (CREAM), which include multiple PSFs. Qualification and quantification of the influencing factors applied in SPAR-H method was adopted for conducting the analysis of PSF or common performance condition (CPC) in CREAM through the comparison of the equality amongst variables of these methods $[6,14,15]$. The results of this study could be combined with other reactor operation scenarios for achieving more comprehensive human reliability analysis of HTGRs. 


\section{THEORY}

\section{HTGR Primary Cooling System}

Gas cooled reactors such as HTGR have specific characteristics and features designed with a high safety level. Passive system and inherent safety systems applied in the design, as well as the absence of the possibility of the reactor melt become the attractive features. Moreover safety is also improved through the availability of sufficient time if the necessary operator action are required during an accident or emergency conditions. For some advanced reactor designs or categorized as generation four, reactors are designed to achieve safe conditions by itself without required short time intervention of operator. In HTGR design, the reserve shutdown system and safe shutdown cooling systems are required to be manually actuated by operator when the outer control rod trip system fails. However during the accident, maximum temperature of HTGR fuel will not exceed $1620{ }^{\circ} \mathrm{C}$ and it can be achieved after several days [16]. Some studies showed that the operator actions in response to the cooling accident tend to be required after approximately 24 hours $[16,17]$.

In the case of new generation of nuclear plant such as HTGR, reducing the acquiring for short term intervention by operator in mitigating the accidents or abnormal events can be realized through the implementation of inherent safety features in the design. However, it should be considered that the problems of the human factor in nuclear reactor operations is not limited to the availability of time for taking appropriate actions/responses. Other factors need to be considered in conducting reactor operations such as the adequacy of procedures and tools, operator understanding to the system, communication among personnel in the control room etc. These factors can also affect the success of operation performed. During the accident operator is also assigned to monitor environmental parameters such as exposure of radioactive and pressure change in the reactor building. In addition, there are some nuclear accident experiences, which show the importance of the human role outside the control room [18,19].

The leakage or loss of coolant in the HTGR primary system can be initiated by the break of primary coolant circulation pipe, a leakage in the pipe system of the steam generator, or a failure of the valve. This accident causes the malfunction of heat transfer through the reactor primary coolant reactor and temperature increase. However, the increase will not exceed the specified limit of maximum fuel temperature. Reactor will automatically scram since the initiating signal is activated, and the temperature will go down by itself due to the use of a passive heat removal system in the design[16]. Moreover the transfer of heat from the core is also accommodated through the reactor cavity cooling system (RCCS). Sample diagram of HTGR primary system components are presented in Figure 1[20]. 


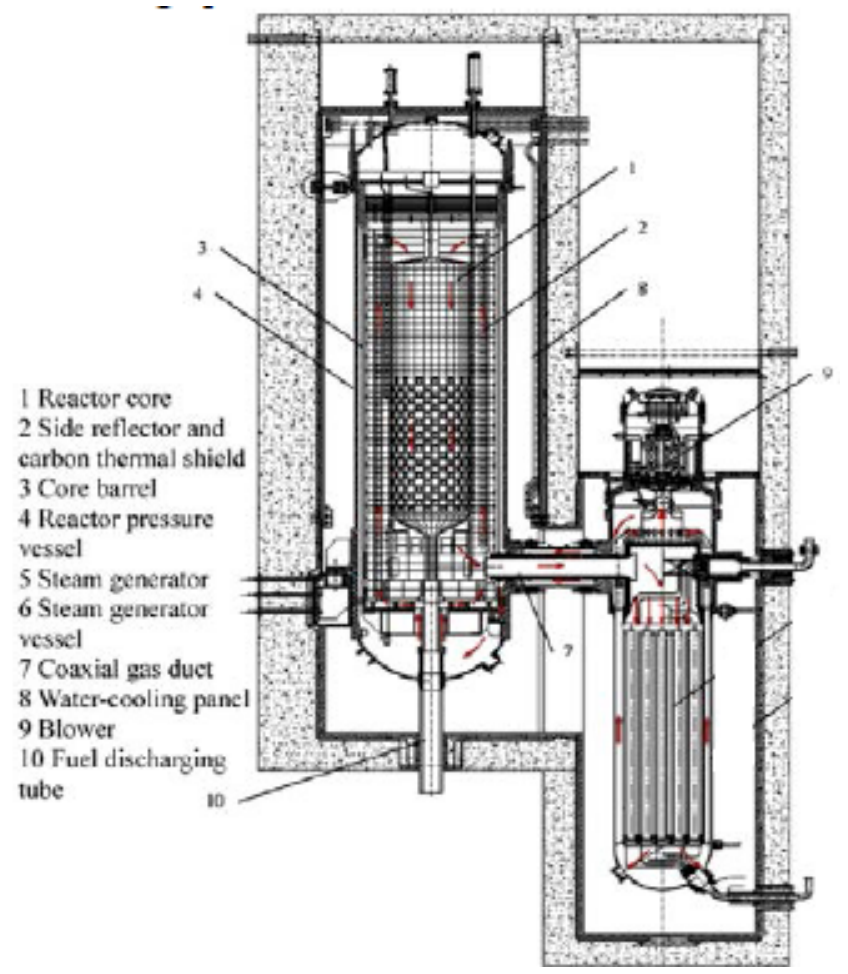

Fig. 1. Primary System of HTGR [21].

\section{Human Performance Shaping Factors (PSF)}

In a qualitative analysis of human reliability, PSF is used to identify all factors contributing and influencing human/operator reliability. Whereas, in the quantitative analysis, PSF is used to calculate the probability of human failure. As shown in equation 1[11], if components of PSF have a positive impact, they will reduce human erro probability (HEP) and, hence, the value of PSF will be smaller than $1(0<\mathrm{PSF}<1$. Inversely, if components of PSF have a negative impact, they will increase HEP and, hence, the value of PSF will be greater than 1 (PSF $>1$ ). Therefore, the value of PSF shows the contribution and importance of PSF components on the operator actions.

$$
H E P_{\text {overall }}=H E P_{\text {nominal }} \times P S F \quad\left\{\begin{array}{ccccc}
0<P S F<1 & \Rightarrow H E P_{\text {overall }}<H E P_{\text {nominal }} & \therefore & \begin{array}{c}
\text { reliability } \\
\text { increases }
\end{array} \\
P S F=1 & \Rightarrow H E P_{\text {overall }}=H E P_{\text {nominal }} & \therefore & \begin{array}{c}
\text { reliability } \\
\text { stays same }
\end{array} \\
P S F>1 & \Rightarrow H E P_{\text {overall }}>H E P_{\text {nominal }} & \therefore & \begin{array}{r}
\text { reliability } \\
\text { decreases }
\end{array}
\end{array}\right.
$$

The stage for qualifying the human error in the reactor operation can be classified as the process of identification the likelihood of error and tendency, and contributing factors to the incidence. This identification process should be performed comprehensively in order to determine the factors that influence to the process entirety. During the identification stage, screening of the influencing factors are conducted through selection based on the contribution value of those factors. The influence factors are then considered further based on the likelihood of the operator error and its trend. Each of PSF components are assessed with considering on the available and necessary information for determining its effect on operator performance.

There is a categorization model on the determining PSF to be used in the identification process. The model which is based on Nureg CR1278 [4] split the PSF as external factors, internal factors and stressors. External factors include all aspects outside the human operator such as 
working environment, tool and equipment. The internal factors are related to the operator mental and competence and other operator features, and stressor is related to all aspects that affect the physical and psychological workload of operators. In simple terms, the process of taking action by an operator can be separated into two stages that are the process / stage of diagnosis and execution stage. The curve of human reliability in the diagnosis as a function of time is given in Figure 2 [4]. Nominal curve shows the failure probability in diagnosis during the abnormal occurrence that is known by the operator or have already acquired in the training.

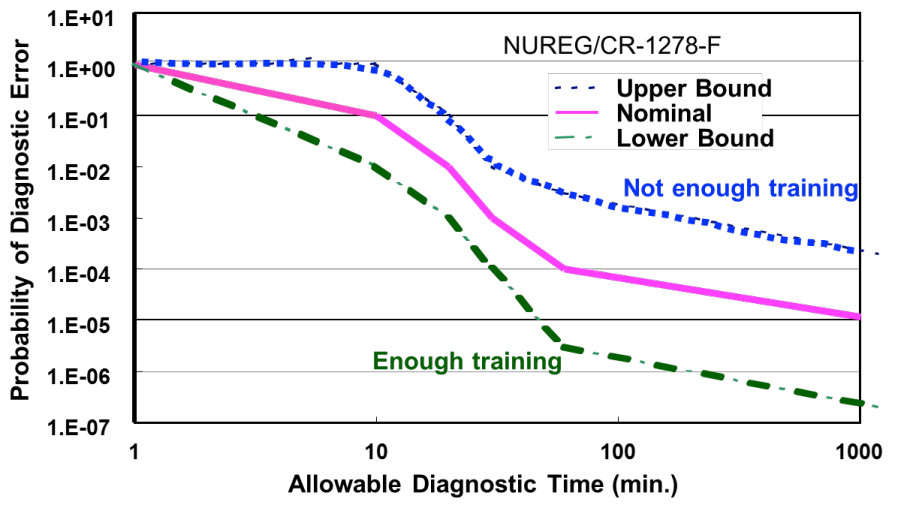

Fig. 2. Human reliability curve on the diagnostic as a function of time [4].

\section{Cognitive Reliability and Error Analysisis Method (CREAM)}

In the human reliability analysis, categorization of operator error in response to the accidents/incidents or taking remedial actions are determined as $\mathrm{C}$ category which then can be distinguished as errors in diagnosis and errors in execution $[8,11]$. Up to this time, many human reliability analysis methods were developed. Cognitive Reliability and Error Analysis Method (CREAM) aims to include the cognitive processes that occur in the construction of operator actions more systematically in the calculation of human reliability. Human action is considered not only as a single act sequential execution but also as a integrated activities performed to achieve the target that is constantly changing as a function of time and processes that experienced. Therefore, actions priority can be changed according to the conditions and targets. In the CREAM, influential aspects considered in the analysis includes the technical aspect, and aspect related to human and organizational factors. In this approach, the time has influence on two things: the first is the flexibility to evaluate the incidence, develop an action plan and take an action. The second thing is the process of change that occurs in the system, and updating the information of the changes[6,21]. The combination simultaneously to both of these as a function of time will determine the process of identification of events/situations, decisions and actions are correct. The contextual control model of CREAM comprises of three main concepts that are competence, control and construction.

There are nine factors called common performance conditions (CPC) as the performance shaping factors in CREAM. Those factors are the adequacy of training, availability of plans and procedures, the adequacy of human machine interface (HMI), availability of time, the number of simultaneously target, the quality of cooperation, organizational factors, environmental conditions and the work cycle as shown in Figure 3[22]. In the quantification of human/operator error probability, the task analysis is required in order to identify the operator actions and activities, including the common performance conditions that affect to the probability of human error. The determination is based on the analysis result to define the factors that contribute to human error, namely, positive contribution (factors reducing the error probability), negative contribution (factors increasing the probability of error ), and did not have a significant impact to the error probability( nominal ). 


\section{The Standardized Plant Analysis Risk - Human Reliability Analysis (SPAR-H)}

Another method called the Standardized Plant Analysis Risk - Human Reliability Analysis (SPAR-H) also includes the cognitive aspect into its consideration. There are eight PSFs applied in SPAR-H those are experience/training, procedures, ergonomics, availability of time, complexity, work processes, stressor, the suitability of the task [14]. The method was developed as a simple-touse approach for risk analysts to compute HEPs. For example, the multiplier factor for the condition with no procedure available equal to 50 , on the other hand if the procedure completed with a systematic structure, the multiplier factor is 0.5 . The multiplier factor of PSF in the activity of operators during the diagnostic process and action implementation process is tend to be similar. Qualification for the multiplier factor of performance shaping factors for each conditions is elaborated in the NUREG CR 6883 document. Completeness of information and data from each PSF conditions will affect to the determination and qualification process.

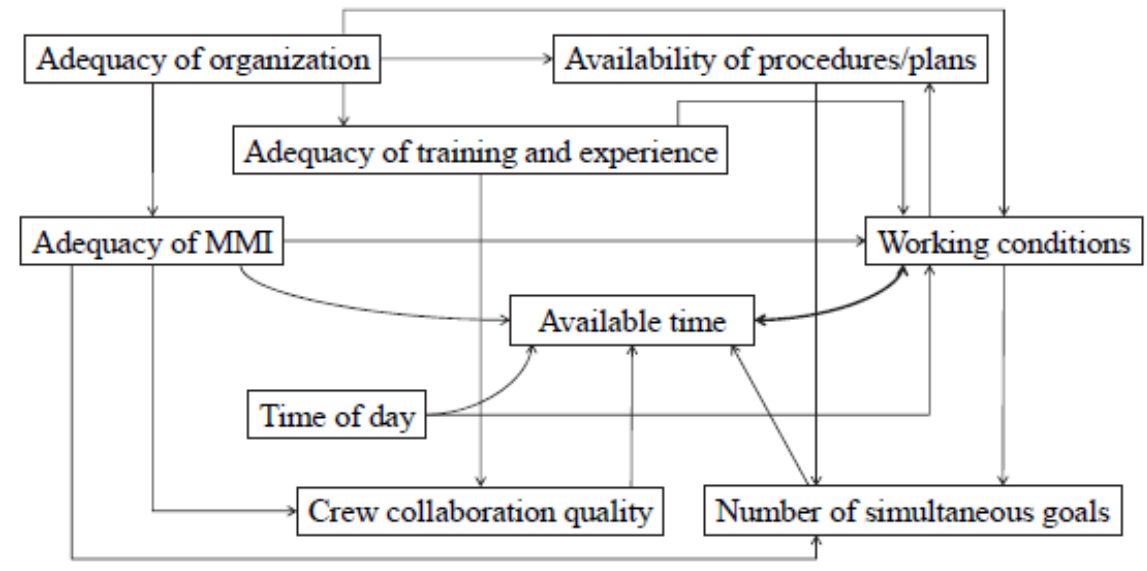

Fig. 3. CPCs in CREAM and the dependencies [22].

\section{METHODOLOGY}

Analysis of the performance shaping factor of HTGR is conducted based on the operator task in controlling heat removal during the leakage of primary coolant accident scenario. The process includes identifying factors influencing the operator response during the accident. Characteristics of HTGR operation and control features on accident conditions are used as a basis in determining the PSF. The method for defining the influence and contribution of PSF are based on human reliability curve as a function of time (HRC) and CREAM analysis method which is based on cognitive approach. In this case, time availability is considered as a single PSF and the human reliability curve is used to determine the PSF value. On the other hand, the implementation of CREAM for defining the values of PSFs' set components consists of the following steps. The first step is to identify the relevant common performance conditions (CPC) in the colling accident. The second step is aimed at identifying the elements or subitems of CPC based on the PSF taxonomy in the accident conditions. The final step is to quantify those influenced factors in CREAM based on the CPC and its conformance to the factor element in SPAR-H method as given in NUREG CR-6883. For this purpose cognitive process or diagnosis stage is assumed as a dominant factor rather than execution stage. Collected data and information regarding operation scenarios, system conditions and operator will be used as a basis in determining the contribution of coresponding influential factors on the operator error probability. The subjective judgement is applied in the process based on the description of the context in the analysis. 


\section{RESULTS AND DISCUSSION}

During the leakage of HTGR coolant, it can be identified that the time availibility for conducting diagnosis and action is much greater than the required time (expansive time). In this case, operator action related to cognitive aspect such as diagnosis and determining an appropriate action need more time than for executing the action. However, if all safety features work properly as in the design, based on the previous data studies, operator is not required to intervene or take any action during at least within the 24 hours, since the inherent safety and systems features, such as RCCS will dissipate the heat and then cool the reactor. It can be assumed that during this period operator will be able to recognize the availability of the safety features in response to the accident and take appropriate actions before the reactor goes to recriticality or core temperature exceeds the safety limit, in case the safety features do not work.

The operating organization and the control room are also well designed in HTGR. Moreover the cooling accident is classified as common accident scenario that should be included in the operator training material. It means that the human operators can be considered as high competence and hence they have complete understanding on the accident scenario described in the training. From the human reliability curve as presented in Fig. 2, it can be determined the operator failure probability during 100 to 1000 minutes is between $1 \times 10^{-4}$ and $1 \times 10^{-5}$. The human error probability after 24 hours would be much less than $1 \times 10^{-5}$. Therefore, based on the task processing stage as applied in SPAR-H model it can be determined that multiplier factor of PSF approximately equal to 0.001 , which can be found by dividing the human error probability of HRC with the nominal diagnosis error probability $\left(1 \times 10^{-5} / 0.01\right)$. The result indicates that time availability in anticipation of primary cooling accident of HTGR has positive contribution in reducing operator error probability especially in the diagnosis process $(\mathrm{PSF}<1)$. If the design of safety features do not work then the value of this contribution will decline because of reducing time availability.

Analysis of the cognitive approach in CREAM does not treat the operator acts as a series of single actions which has fixed objectives and priorities. Objectives and priorities are more determined by a process that would change any time. Accordingly, the performance shaping factors are not merely influenced by time variable, but also the conditions during the process. Therefore, all CPCs of CREAM are identified as relevant PSF to the operator actions in the operator response during the cooling accident.

Identification of the elements for each CPC was conducted based on the PSF taxonomy and characteristics of operator action in response to the accident. The analysis of conditions and features in HTGR design which are relevant to the CPCs are perfomed based on the available collected design information and operation requirement. The elements of CPC and the associated conditions in the HTGR design are presented in Table 2.

Table 2. CPC and corresponding conditions in HTGR design

\begin{tabular}{|c|c|c|c|}
\hline No & CREAM-CPC & Elements & Conditions in HTGR Design \\
\hline 1 & $\begin{array}{l}\text { Adequacy of training and } \\
\text { preparation }\end{array}$ & $\begin{array}{l}\text { Training program ,simulator, } \\
\text { Operator skill and experience }\end{array}$ & $\begin{array}{l}\text { Effective training program, } \\
\text { simulator based training system, } \\
\text { exploited new technology/modern } \\
\text { tools in control room design, high } \\
\text { criteria and qualified operator }\end{array}$ \\
\hline 2 & $\begin{array}{l}\text { Availability } \\
\text { procedures, planning }\end{array}$ & $\begin{array}{l}\text { Availability, format or type, } \\
\text { logic structure, clarity of } \\
\text { instruction }\end{array}$ & $\begin{array}{l}\text { completeness and accessibility of } \\
\text { procedure, not sufficient reactor } \\
\text { operating experience. }\end{array}$ \\
\hline 3 & $\begin{array}{l}\text { Adequacy of HMI } \\
\text { (Human Machine } \\
\text { Interface) and operational } \\
\text { support }\end{array}$ & $\begin{array}{l}\text { Information availability, } \\
\text { workstation, control display } \\
\text { design, alarm } \\
\text { usability }\end{array}$ & $\begin{array}{l}\text { Advance HMI design and support } \\
\text { system, error tolerance, high } \\
\text { usability, clearly and mature } \\
\text { information, computerized based } \\
\text { procedure }\end{array}$ \\
\hline 4 & Available time & Available time vs require time & $\begin{array}{l}\text { Minimize operator intervene, expand } \\
\text { time for taking actions. }\end{array}$ \\
\hline
\end{tabular}




\begin{tabular}{|c|c|c|c|}
\hline No & CREAM-CPC & Elements & Conditions in HTGR Design \\
\hline 5 & $\begin{array}{l}\text { Number of simultaneous } \\
\text { goals }\end{array}$ & $\begin{array}{l}\text { Priority among tasks/ goals, } \\
\text { number of goals, operation } \\
\text { charateristics }\end{array}$ & $\begin{array}{l}\text { Multi functions, complex operator } \\
\text { task, simultaneous goals, } \\
\text { moderately complex. }\end{array}$ \\
\hline 6 & collaboration & $\begin{array}{l}\text { Clearness in role and } \\
\text { responsibility,communication, } \\
\text { trust level }\end{array}$ & $\begin{array}{l}\text { Appropriate communication system, } \\
\text { management of task and authority, }\end{array}$ \\
\hline 7 & Adequacy of organization & $\begin{array}{l}\text { Plant policy, structure control } \\
\text { room personel, safety } \\
\text { management system }\end{array}$ & $\begin{array}{l}\text { Well established organization, } \\
\text { Appropriate task distribution and } \\
\text { personel management }\end{array}$ \\
\hline 8 & Working conditions & $\begin{array}{l}\text { physical working } \\
\text { environment, Stress/stressors, }\end{array}$ & $\begin{array}{l}\text { Appropriate and adjustable physical } \\
\text { working environment, Multiple units } \\
\text { and interconnections process in a } \\
\text { reactor site. }\end{array}$ \\
\hline 9 & $\begin{array}{l}\text { Working cycle/time of } \\
\text { day }\end{array}$ & $\begin{array}{l}\text { Staffing, work load, fitness } \\
\text { for duty }\end{array}$ & $\begin{array}{l}\text { Reducing control room crew, } \\
\text { declining operator redundancy, } \\
\text { Operator shift transfer. }\end{array}$ \\
\hline
\end{tabular}

Interactions of operator with the reactor system are mainly conducted in the control room. In the modern control room design operator error during the task execution can be substantially reduced or anticipated by the implementation of error tolerance and error correction (error recovery) on the design. Particularly in the design of human machine interface components, such as information presentation and control input device. Thus, in the advanced control room design such as HTGR control room, it can be considered that the operator errors tend to be more exists in cognitive process rather than execution process.

The analysis result of the common performance conditions in CREAM and the relationship with the factors in SPAR-H are given in Table 3. Method for qualification of multiplier factor of performance shaping factors is provided in the NUREG CR 6883 document. From those results as presented in the Table 3, it can be obtained that the total multiplier factors of PSF equal to 0.25. Performance shaping factors that contribute to the increasing of operator error probability are the completeness of the procedure, the duty cycle, and the working environment. On the contrary PSFs which contribute in reducing the operator error probability are the adequacy of training, adequacy of HMI and support system, as well as the availability of time. Availability of time become the dominant factor in reducing the multiplier factor of PSF, that equal to 0.01 . The expansive time of $\mathrm{CPC}$ component resulted the probability of operator error in conducting diagnosis is $1 \times 10^{-4}$.

Table 3. Analysis result on PSF and multiplier factors

\begin{tabular}{llllc}
\hline No & \multicolumn{1}{c}{ CREAM-CPC } & SPAR-H-PSF & Level/quality & $\begin{array}{c}\text { HEP(Multiplier } \\
\text { factors) }\end{array}$ \\
\hline 1 & $\begin{array}{l}\text { Adequacy of training and } \\
\text { preparation }\end{array}$ & Training/Experience & Good/High & $0.005(0.5)$ \\
2 & $\begin{array}{l}\text { Availability of procedures, } \\
\text { planning }\end{array}$ & Available, but poor & $0.05(5)$ \\
3 & $\begin{array}{l}\text { Adequacy of HMI (Human } \\
\text { Machine Interface) and }\end{array}$ & Ergonomics/HMI & Good/Appropriate & $0.005(0.5)$ \\
& $\begin{array}{l}\text { operational support } \\
4\end{array}$ & Available time & Available time & Expansive time \\
5 & Number of simultaneous & Complexity/stressor & Moderately complex & $10^{-4}(0.01)$ \\
& goals & Nominal & $0.02(2)$ \\
6 & Crew collaboration quality & Work processes & $0.01(1)$ \\
7 & Adequacy of organization & Work processes & Nominal & $0.01(1)$ \\
8 & Working conditions & Stress/stressors & High & $0.02(2)$ \\
9 & Working cycle/time of day & Fitness for duty & Degraded fitness & $0.05(5)$ \\
\hline
\end{tabular}




\section{CONCLUSION}

There are some factors contribute to the reactor operator reliability of HTGR. Identification of the factors influencing human reliability during primary coolant accident of HTGR showed that a time availability is a main contribution in reducing the probability of operator error, especially when the safety features for heat conversion/dissipation system work properly as in the design. HTGR safety system design affected the time required for operator to diagnose and to take anticipatory action are much smaller than the available time(expansive time). From the analysis method using reliability curve, it was found that a multiplier factor of PSF equal to 0.001 (PSF $<1$ ). However, the result of the study also identify that in addition to the available time other PSFs are also essential. The cognitive-based method CREAM indicated a multiplier factor for a time variable and overall PSF are 0.01 and 0.25 respectively. Influenced factors with positive contribution to the operator reliability are the adequacy of training, adequacy of HMI and supports, and availability of time. On the contrary the negative contribution is resulted from the completeness of the procedure, the duty cycle and the working environment.

\section{ACKNOWLEDGEMENT}

This research was a part of research project supported and funded by the Nuclear Research $\&$ Development Program (DIPA 2015) at the Center for Nuclear Reactor Technology and Safety, National Nuclear Energy Agency of Indonesia.

\section{REFERENCES}

1. Kim S. K., Byun S. N. Effects of Crew Resource Management Training on the Team Performance of Operators in an Advanced Nuclear Power Plant. Journal of Nuclear Science and Technology 2012; 48(9):1256-1264,

2. Wu Ji-Tsung Ben, and Marakas, George M. The Impact of Operational User Participation on Perceived System Implementation Success: An Empirical Investigation. Journal of Computer Information Systems 2006; 46(5):127-40.

3. Leva M. C., Pirani R., De Michela M., Clancy P. Human Factors Issues and the Risk of High Voltage Equipment. Journal Chemical Engineering Transactions 2012; 26:273-278.

4. Swain A.D., Guttmann H.E. Handbook of Human Reliability Analysis with Emphasis on Nuclear Power Plant Applications, NUREG/CR-1278. US Nuclear Regulatory Commission, Washington D.C., America, 1983.

5. Demichela M., Pirani R., Leva M.C. Human Factor Analysis Embedded in Risk Assessment of Industrial Machines: Effects on the Safety Integrity Level. International Journal of Performability Engineering 2014; 10(5):487-496.

6. Pin-Chao Liao, Xintong Luo, Tao Wang, Yusong Su. The Mechanism of how Design Failures cause Unsafe Behavior: The Cognitive Reliability and Error Analysis Method (CREAM). Procedia Engineering 2016; 145:715-722

7. Zhiqiang Sun., Hongwei, X., Xujian, S., Fenggiang. Engineering Approach for Human Error Probability Quantification. Journal of System Engineering and Electronics 2009; 20(5):1144-1152.

8. Chang, Y.H.J., and Mosleh, A. Cognitive modeling and dynamic probabilisitic simulation of operating crew response to complex system accidents, Part 2: IDAC performance influencing factors model. Reliability Engineering and System Safety 2007; 29:10141040.

9. Kim MC., Seong PH., Hollnagel, E. A probabilistic approach for determining the control mode in CREAM. Reliability Engineering and System Safety 2006; 91(2):191-199. 
10. Braseth A.O., Nihlwing C., Svengren, H., et al,. Lessons learned from Halden project research on human system interfaces. Nuclear Engineering and Technology 2009; 41(3):215-224.

11. Kim MC., Seong PH. An analytic model for situation assessment of nuclear power plant operators based on Bayesian inference. Reliability Engineering and System Safety 2006; 91:270-82.

12. Monferini A., Konstandinidou M., Nivolianitou Z., Weber S., Kontogiannis T., Kafka P., Kay A.M, Leva M.C., Demichela M. A Compound Methodology to Assess the Impact of Human and Organizational Factors Impact on the Risk Level of Hazardous Industrial Plants. Reliability Engineering and System Safety 2013; 119:280-289.

13. Lee SW., Kim AR., Ha JS., and Seong, PH. Development of a qualitative evaluation framework for performance shaping factors in advanced MCR HRA, Annals of Nuclear Energy 2011, 38(8):1751-1759.

14. Gertman D., Blackman H., Marble J., Byers J., Haney L., and Smith C. The SPAR-H human reliability analysis method, NUREG/CR-6883, US Nuclear Regulatory Commission, 2005, Washington, DC.

15. Seung Jun Lee, Jaewhan Kim, Seung-Cheol Jang, Yeong Cheol Shin. Modeling of a Dependence between Human Operators in Advanced Main Control Rooms, Journal of Nuclear Science and Technology 2009; 46(5):424-435.

16. IAEA, Status Report 70 - Pebble Bed Modular Reactor (PBMR), International Atomic Energy Agency, 2010.

17. Ball S.J. Overview of Modular HTGR Safety Characterization and Postulated Accident Behavior Licensing Strategy, Oak Ridge National Laboratory, May 2014

18. O'Hara J.M., Higgins J.C., and Brown, W.S. Nuclear Engineering Technology Journal. 2009; 41:225-236.

19. Lee HC., Seong, PH. Acomputational model for evaluating the effects of attention, memory, and mental models on situation assessment of nuclear power plant operators. Reliability Engineering and System Safety 2009; 94(11):796-805.

20. Zhou K., Zhou Y., Ma Y., et al. Simulation of Thermal-Hydraulic Process in Reactor of HTR-PM Based on Flow and Heat Transfer Network. Atomic Energy Science and Technology Journal 2012; 46:918-926.

21. Konstandinidou M., Nivolianitou Z., Kiranoudis C., Markatos N. A Fuzzy Modeling Application of CREAM Methodology for Human Reliability Analysis. Reliability Engineering and System Safety 2006; 91(6):706-716.

22. Takemoto T., Mitomo N., Hikida K., and Yoshimura K. A Study on Human Factors Analysis for Possible Factors of Marine Accident-Modifying CPC for Marine Accident Analysis, The Journal of Japan Institute of Navigation 2012; 127:95-101. 